\title{
NARRATIVA TRANSMÍDIA E TRANSFICCIONALIDADE
}

MARIE-LAURE RYAN discute como histórias migram para outros meios ou como atualmente projetos artísticos já são concebidos em diferentes meios

Neste[1] artigo[2], busco investigar as relações entre o conceito narratológico de transficcionalidade - definido por Richard Saint-Gelais como uma relação que se estabelece quando "[d]ois ou mais textos [...] partilham elementos, tais como personagens, locações imaginárias, ou universos ficcionais" [3] - e um fenômeno que hoje vem arrebatando a cultura popular, conhecido de modos diversos como narrativa convergente, transmidiática ou transmídia[4]. Henry Jenkins concebe tal fenômeno como "o fluxo do conteúdo por meio de múltiplas plataformas de mídia"[5]. A dinâmica inerente à metáfora do fluxo sugere que o conteúdo se desenvolve enquanto passa de uma mídia para outra, configurado pelas disposições particulares dessas mídias. No entanto, Jenkins também descreve a narrativa transmídia, como a chamarei aqui, por meio de uma fórmula que sugere outra visualização: “Uma narrativa tão ampla, que não é abarcável por uma única mídia”[6]. Aqui, é possível imaginar várias mídias ávidas por alcançar um conteúdo fixo e predefinido, para tomar um pedaço. Poderíamos argumentar que essas duas fórmulas são mais frases de efeito do que definições (por exemplo, o que torna uma narrativa "ampla"? por certo não será o seu tamanho), porém as frases de efeito memoráveis têm um jeito poderoso de promover novas ideias e iniciar discursos teóricos[7].

É tentador observar a narrativa transmídia como algo radicalmente novo e revolucionário, ou ao menos como a forma narrativa do futuro; porém historiadoras poderiam perspectivar tal afirmação, se apontassem a disseminação do mito grego em várias mídias artísticas escultura, arquitetura, drama, épica - ou, mais próximo de nós, os 
múltiplos modos de distribuição das narrativas bíblicas na Idade Média. Essas narrativas não eram apenas escritas em livros, que a maioria das pessoas não era capaz de ler, elas eram também recontadas oralmente durante os sermões, encenadas em dramas da paixão, ilustradas em pinturas e vitrais e até inspiravam o fenômeno interativo da Via Sacra, onde peregrinos reviviam a paixão de Cristo enquanto seguiam um itinerário fixo pontuado por capelas. Esse tipo de tratamento multimídia é tipicamente reservado para as narrativas consideradas fundadoras para a identidade de um grupo. Na era da globalização, a função comunitária da narrativa foi assumida por narrativas como Star Wars [Guerra nas Estrelas], Lord of the Rings [O Senhor dos Anéis] e Matrixnarrativas que transcendem fronteiras linguísticas, nacionais e religiosas. Mas, se a propagação de narrativas definidoras de cultura entre mídias é um fenômeno consagrado pelo tempo, hoje ela toma novas formas, impulsionada pela habilidade tecnológica de codificar e transmitir com eficiência todos os tipos semióticos de informação.

A narrativa transmídia aparece em dois gêneros principais, ou melhor, numa variedade de espectros situados entre dois polos. O primeiro polo é o que podemos chamar de efeito "bola de neve": uma determinada narrativa goza de tanta popularidade, ou torna-se tão eminente na cultura, que espontaneamente ela gera uma variedade de prequelas [8] e sequências, ficção de fãs e adaptações, seja na mesma mídia ou entre mídias. Nesse caso, há um texto central que funciona como um campo comum de referência a todos os outros textos. Harry Potter e Lord of the Rings são bons exemplos do efeito bola de neve: ambos começaram na mídia do romance criado por uma única autoria e depois se expandiram para filmes e jogos de computador graças à demanda popular.[9]

O outro polo é um fenômeno muito mais recente. Ele é representado por um sistema em que uma determinada história é concebida desde o início como um projeto que se desenvolve sobre diferentes plataformas de mídia. Universos narrativos [storyworlds] se tornam franquias comerciais, e o interesse de suas criadoras é fazer com que o público consuma tantas mídias quanto possível. Jenkins ilustra a situação com o caso de The Matrix[10]: os irmãos Wachowski planejaram um império narrativo que envolvia não apenas filmes, como também videogames e 
quadrinhos. Os filmes funcionaram para a maioria das pessoas como um ponto de entrada ao sistema, e seriam consumíveis por si mesmos, porém estavam repletos de pistas esotéricas que só seriam decifradas pelas jogadoras. As jogadoras, por sua vez, dependiam do filme para um conhecimento do pano de fundo e das personagens. Nesse caso, como observa Jenkins, os materiais são tão numerosos, e a narrativa é tão rica, que dificilmente alguém detém uma sobrevisão completa do universo narrativo.[11]

\section{UNIVERSOS NARRATIVOS}

A noção de universo narrativo[12] é central para o fenômeno da narrativa transmídia, já que é ele quem amarra os vários textos do sistema. A habilidade de criar um universo, ou mais precisamente, a habilidade de inspirar a representação mental de um universo é a condição primária para um texto ser considerado uma narrativa. Isso nos leva à questão: o que é um universo? O universo narrativo é um conceito que se faz sobretudo por senso intuitivo, mas é muito difícil defini-lo com rigor teórico. Universo [world] sugere um espaço, mas narrativa [story] é uma sequência de acontecimentos que se desenvolve no tempo. Se concebermos os universos narrativos como representações mentais construídas ao longo de uma leitura (visão, jogo etc.) de um texto narrativo, eles não são recipientes estáticos para os objetos mencionados numa narrativa, mas sobretudo modelos dinâmicos de situações em desenvolvimento. Poderíamos dizer: são simulações de um desenvolvimento da narrativa. O famoso crítico russo Mikhail Bakhtin [13] capturou essa indivisibilidade do espaço e do tempo na narrativa através do conceito de cronótopo.

Eu proponho que se defina os universos narrativos através de um componente estático que precede a narrativa e de um componente que captura o desenrolar dos acontecimentos; por exemplo, a narrativa minimalista proposta por E.M. Forster, como exemplar da trama [14] “O rei morreu, depois a rainha morreu de luto", limita-se a 1, 4, 6 e 7. (De modo alternativo, seria possível dizer que o exemplo de Forster falha ao conjurar um universo à imaginação; é por isso que não é uma narrativa contável.) 
Componente estático[15]:

1 - Um inventário dos existentes, que compreende (a) os gêneros das espécie, objetos e instituições sociais que povoam o universo narrativo; (b) o elenco das personagens individuais que atuam como protagonistas 2 - Um relato folclórico dos existentes (panos de fundo, lendas, rumores)

3 - Um espaço com determinadas características topográficas

4 - Uma série de leis naturais

5 - Uma série de regras e valores sociais

Componente dinâmico:

1 - Acontecimentos físicos que tragam mudanças aos existentes 2 - Acontecimentos mentais que deem significância aos acontecimentos físicos (i.e., as motivações dos agentes e as reações emocionais de agentes e pacientes), afetem as relações entre personagens e ocasionalmente alterem a ordem social

Universos narrativos podem apresentar três relações com os textos:

Uma relação de um texto/um universo. Aqui o texto projeta um determinado universo narrativo e é o único modo de se acessar tal universo. Já que usuárias diversas dificilmente construirão o mesmo modelo mental de um texto, é possível argumentar que a relação umpara-um não acontece ao pé da letra, mas, se aderirmos às condições limitadas de igualdade, perderemos a distinção entre esta categoria e a próxima. Assumirei que, se a vasta maioria das usuárias constrói basicamente a mesma sequência de acontecimentos, as mesmas relações causais e as mesmas motivações para as ações das personagens, em outras palavras, se atendem ao que Remigius Bunia[16] chama de "sentido imediato" do texto, elas terão construído o mesmo universo narrativo.

Uma relação de um texto/muitos universos. Essa relação acontece quando o texto é tão indeterminado que é possível relacioná-lo a muitas narrativas diferentes. Algumas pinturas, por exemplo, incitam a espectadora a imaginar uma narrativa que explique a cena que se lhe apresenta; mas, como as pinturas não têm uma extensão temporal, não são capazes de representar uma série fixa de acontecimentos e, assim, 
inspiram interpretações narrativas muito variáveis. Outro exemplo da relação um-para-muitos é o caso de textos digitais, tais como hipertextos ou videogames, onde as escolhas da usuária determinam uma das muitas sequências possíveis para os acontecimentos.

Uma relação um universo/muitos textos. Essa relação é típica da tradição oral. É representada por múltiplas performances de uma mesma narrativa ou chiste, ou por bardos que contam e recontam narrativas sobre os mesmos heróis. Também a encontramos no caso dos resumos de um mesmo texto, ou de adaptações de textos clássicos para audiências jovens.

O fenômeno da narrativa transmídia é, em geral, apresentado por seus teóricos como um exemplo da terceira relação: um universo, muitos textos. Henry Jenkins não utiliza o termo universo, mas descreve a base comum e uma franquia transmídia como "ambientes persuasivos que não são exploráveis por apenas uma obra ou mídia”[17]. Mas seria realmente o "mesmo" universo (dieselbe Welt) que as várias encarnações de The Matrix, ou de Star Wars, ou de Lord of the Rings apresentam, ou um universo similar (eine gleiche Welt)? Tentarei responder essa questão mais adiante; mas, como passo preliminar, devemos primeiro examinar o conceito narratológico de transficcionalidade.

\section{TRANSFICCIONALIDADE}

Como já vimos, o termo transficcionalidade[18] refere-se à migração de entidades ficcionais de diferentes textos, mas esses textos podem pertencer à mesma mídia, em geral à ficção narrativa escrita. A narrativa transmídia pode ser encarada como um caso especial de transficcionalidade - uma transficcionalidade que opera entre muitas mídias diferentes.

De acordo com o teórico literário Lubomír Doležel[19], um universo ficcional estaria a outro por três tipos de relações: expansão, modificação e transposição[20].

A expansão amplia o escopo do universo narrativo original ao acrescentar mais existentes, ao transformar personagens secundárias em 
heróis da narrativa que elas vivem, ao fazer com que personagens visitem novas regiões do universo narrativo e ao expandir o tempo coberto pela narrativa original através de prequelas e sequências. Doležel ilustra a relação de expansão com um debate sobre Wide Sargasso Sea [Vasto Mar de Sargaço] (1966). O romance segue a vida de uma personagem menor de Jane Eyre, de Charlotte Brontë: a personagem da primeira esposa de Mr. Rochester, que aparece no texto original apenas como uma louca trancada no sótão. Em Wide Sargasso Sea, ela recebe o que lhe foi negado em Jane Eyre, a saber, a oportunidade de narrar sua vida do seu próprio ponto de vista.

A modificação "constrói essencialmente versões diferentes de um protouniverso, ao redesenhar sua estrutura e reinventar sua narrativa" [21]. De acordo com Doležel, essa relação acontece entre Robinson Crusoe de Daniel Defoe e Foe (1988) de J.M. Coetzee. Em Foe, Robinson não se engaja em nenhum dos atos heroicos e civilizatórios do romance original, nem escreve um diário: sua história é o trabalho de um escritorfantasma. A maior parte dos exemplos literários de modificação apresenta uma sequência contrafactual dos acontecimentos, ao apresentar um destino diferente para as personagens. Eles respondem à pergunta: “e se?”[22]

A transposição. Essa operação "preserva o desenho e a história central do protouniverso, mas os aloca numa ambientação temporal ou espacial diferente" [23]. O exemplo de Doležel é Os Novos Sofrimentos do Jovem $W$., de Ulrich Plenzdorf (1973), um romance que transplanta a trama de Os Sofrimentos do Jovem Werther de Goethe para a República Democrática da Alemanha dos anos 60[24].

Às três relações descritas por Doležel eu gostaria de acrescentar a citação. Exemplos de citação seriam uma personagem de um dos filmes de Lord of the Rings usando um sabre de luz emprestado de Star Wars, ou um vídeo amador no YouTube que apresenta uma personagem trajando a máscara de Darth Vader num cenário do subúrbio americano que nada tem a ver com a trama de Star Wars [25]. Nesse caso, o elemento importado não se integra ao universo narrativo, e o efeito é de dissonância e incongruência. Esse efeito tem um papel importante na 
estética dadá e surrealista.

\section{MESMO UNIVERSO VS. MUITOS UNIVERSOS EM SISTEMAS DE NARRATIVA TRANSMÍDIA}

A relação de expansão é muito mais dada à preservação do universo do que a modificação e as transposições, porque ela não requer uma mudança em nenhum dos fatos sustentados na narrativa original. Tal diferença nos convida a concluir que as expansões se referem ao mesmo universo, ao passo que a modificação e a transposição se refeririam a universos relacionados, porém diferentes. Mas há um problema nessa visão. Imagine que uma autora escreva um romance, depois outra autora escreva uma sequência ou prequela: poderíamos considerar os dois textos como referências ao mesmo universo? A situação é certamente diferente do caso de uma autora que escreve uma sequência ou prequela para seu próprio texto, ou usa o recurso do retorno das personagens. Não vejo problema em chamar o universo dos vários filmes de Star Wars de o mesmo universo - todos foram concebidos por um grupo coordenado por George Lucas. Mas consideremos o exemplo das novas aventuras de Dom Quixote publicadas em 1614 por Alonso Fernández de Avellaneda: será que elas têm lugar no mesmo universo que o Quixote de Cervantes? Quando Cervantes tomou conhecimento do texto de Avellaneda, decidiu escrever sua própria sequência, e essa é a segunda parte de Dom Quixote. Se os três textos são vistos como referentes ao mesmo universo, esse universo vai apresentar contradições lógicas, uma vez que Dom Quixote realiza alguns feitos - aqueles relatados por Avellaneda - e não os realiza, porque não são narrados por Cervantes. É possível perceber a diferença entre as sequências de Cervantes e Avellaneda se virmos que o primeiro expande o mesmo universo, enquanto o segundo cria um novo universo que contém o universo do Dom Quixote de Cervantes (ou, ao menos, o universo da parte 1). Quanto aos universos das modificações e transposições, eles estabelecem uma relação de sobreposição com o universo original. Os universos dos textos transficcionais, desse modo, se relacionariam com o universo original de três maneiras diferentes: sobreposição, inclusão e o mesmo universo ampliado (ver figura 1). 


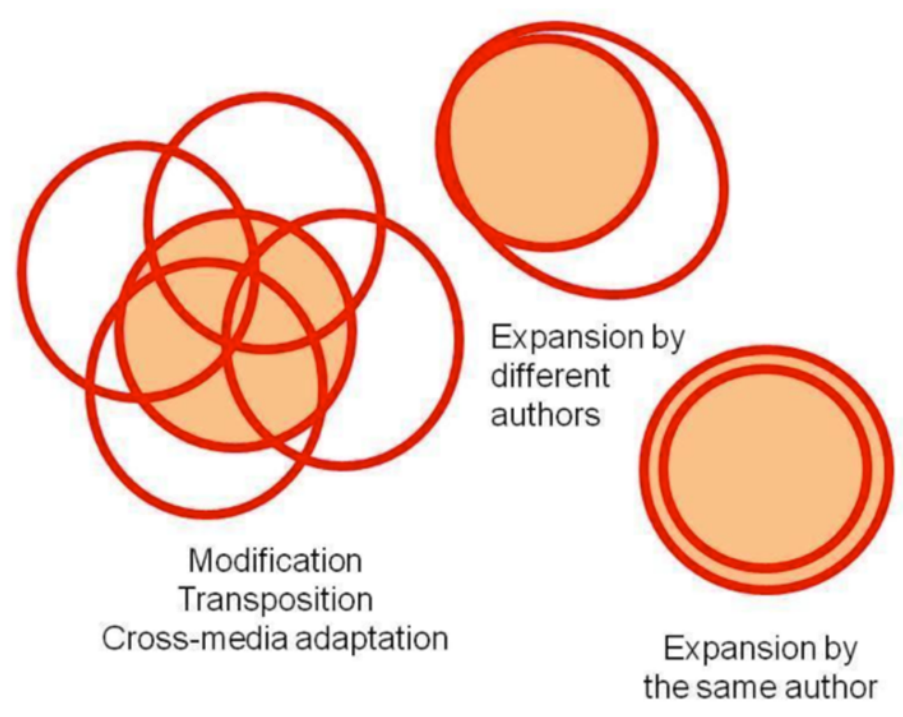

Figura 1_Relações entre universos narrativos em sistemas transficcionais e transmídia. (A área sombreada é o universo narrativo do texto original.)

Outra operação que cria uma relação entre universos narrativos, porém sem fundi-los num só, é a operação de adaptação transmídia. Já que mídias diferentes apresentam recursos diferentes, por lhes dar uma potência expressiva diferente, é virtualmente impossível que duas mídias diferentes projetem o mesmo universo. Por exemplo, a diferença entre romance e cinema: num romance, os pensamentos das personagens são representáveis explicitamente e com maior detalhamento; num filme, os recursos para realizar tal representação são muito mais limitados, o estado mental das personagens deve, em geral, ser inferido pela espectadora, que toma por base os sinais visuais. Outra diferença importante diz respeito à aparência. Num filme, sabemos imediata $\mathrm{e}$ inteiramente a aparência das personagens, e isso permite que façamos inferências sobre outras características de sua persona. Num romance, por outro lado, a aparência permaneceria inespecífica, e quando uma personagem é introduzida pela primeira vez, é possível que nada saibamos dela além de um nome ou de uma expressão. Quando as personagens são descritas, a descrição vem em partes e deixa muitas lacunas por serem preenchidas. 
Além das diferenças que derivam da própria mídia, as adaptações difeririam do original graças a cada uma das três principais operações transficcionais acima definidas[26]. Uma operação comum é expandir o universo original pelo acréscimo de novas personagens: por exemplo, a versão cinematográfica de The French Lieutnenant Woman [A Mulher do Tenente Francês], de John Fowles (1981, dirigido por Karel Reisz), acrescenta uma equipe cinematográfica moderna às personagens do século dezenove tomadas do romance e apresenta a narrativa dessas personagens como o roteiro do filme cuja produção é representada. Uma adaptação também modificaria a trama ao lhe dar um novo fim, como a versão animada de Walt Disney para The Little Mermaid [A Pequena Sereia] (1989, dirigido por Ron Clements e John Musker), que termina com a sereia junto ao príncipe, em vez de se dissolver numa espuma; ou transporia a trama para um universo diferente, como o filme Bride and Prejudice [Noiva e Preconceito] (2004, dirigido por Gurinder Chadha), que realoca a trama de Pride and Prejudice [Orgulho e Preconceito], de Jane Austen, num cenário indiano, para realizar uma paródia dos filmes de Bollywood. Mas também existem adaptações que buscam minimizar as diferenças: por exemplo, se compararmos o filme Jurassic Park [Parque dos Dinossauros] ao romance de Michael Crichton, que também escreveu o roteiro para o filme.

Num sistema narrativo transmídia, a relação mais comum entre os vários documentos é a expansão: por exemplo, se há um videogame a partir de um filme, o jogo pode inventar uma nova personagem para a jogadora controlar; ou se centrar num aspecto do universo narrativo que permanece sem desenvolvimento em outras versões. Carlos Scolari[27] menciona três gêneros de expansões: narrativas de interstício, que têm lugar entre os capítulos de uma série (é possível também situar as prequelas e sequências nessa categoria, já que elas expandem o período abarcado pelo documento original); narrativas paralelas acontecem ao mesmo tempo que a narrativa original, por exemplo, ao desenvolverem o destino de uma personagem secundária; e narrativas periféricas, "que podemos considerar como mais ou menos satélites de uma macronarrativa" (2009:598). Eu consideraria como narrativas periféricas o folclore e as lendas que se relacionam aos objetos de um universo narrativo[28]. 
A relação de modificação é muito menos comum que a expansão em projetos transmídia, porque ameaça a integridade do universo narrativo original, porém não é inaudita: por exemplo, o jogo Star Wars: The Force Unleashed transporta a jogadora para um universo contrafactual onde o Lado Negro de Darth Vader e do Imperador prevalecem sobre a Força, enquanto nos filmes acontece o contrário. Nesse caso, a relação entre o universo dos filmes e o universo do jogo é parcialmente uma questão de trama - nos dois casos, há uma guerra entre a Força e o Lado Negro -, mas majoritariamente uma questão de nomes, objetos e leis da natureza, e sobretudo de aparência visual.É porque uma determinada personagem se chama Darth Vader, porque ele parece um herói nos filmes, e porque a arma principal utilizada pela personagem é um sabre de luz, que o universo do jogo The Force Unleashed é percebido como uma versão do universo de Star Wars. A modificação é também muito eminente nos textos apócrifos criados pelas fãs; por exemplo, existe todo um gênero chamado Ficção de corte [Slash Fiction] [29] que altera as preferências sexuais de personagens famosas de cinema ou TV.

No entanto, penso que a terceira relação, a transposição, não seja compatível com o espírito das franquias transmídia modernas. Se a trama de Star Wars fosse transportada para um ambiente diverso, por exemplo, para um universo de fantasia medieval, ninguém a reconheceria como uma versão de Star Wars apenas porque sua trama apresenta inúmeras narrativas sobre a luta entre o bem e o mal[30]. O que torna distinto o universo narrativo de Star Wars não é a trama, mas o cenário, e se o cenário é alterado, todo o universo narrativo perde sua identidade.

Quanto à relação de citação, ela pode ser vista em paródias, mas apresenta um desafio ainda maior que a transposição para o espírito da narrativa transmídia, porque, ao questionar a unidade e autonomia do universo narrativo, ela cria um distanciamento irônico sobre tal universo que impede a imersão.

As relações entre os elementos de um projeto transmídia podem ser descritas não apenas em termos de relações semânticas - tais como expansão, modificação e transposição -, mas também em termos de status legal. Um típico projeto bola de neve, como a franquia Star Wars, 
consiste em três tipos de elementos (figura 2): (1) Um cerne de documentos canônicos, - aqui, os seis filmes de George Lucas - que expandem o mesmo universo. (2) Adaptações transmídia, tais como os jogos individuais e os universos online para várias jogadoras (MMORPG's), que são produzidos por diferentes empresas que operam sob licença. Os universos desses textos tendem a ser expansões, porque precisam ser aprovados pelas criadoras originais: por exemplo, a empresa de George Lucas provavelmente não aprovaria uma adaptação de Star Wars que não oferecesse uma boa diversão segura para toda a família. Eu represento tais expansões com círculos em interseção, em vez universos mais amplos que contenham o original, porque são também adaptações entre mídias. (3) Documentos apócrifos produzidos pelas fãs. Aqui a operação de modificação será muito mais prevalente do que nos produtos licenciados, porque ela permite que as fãs apresentem uma atitude satírica em relação ao universo original.

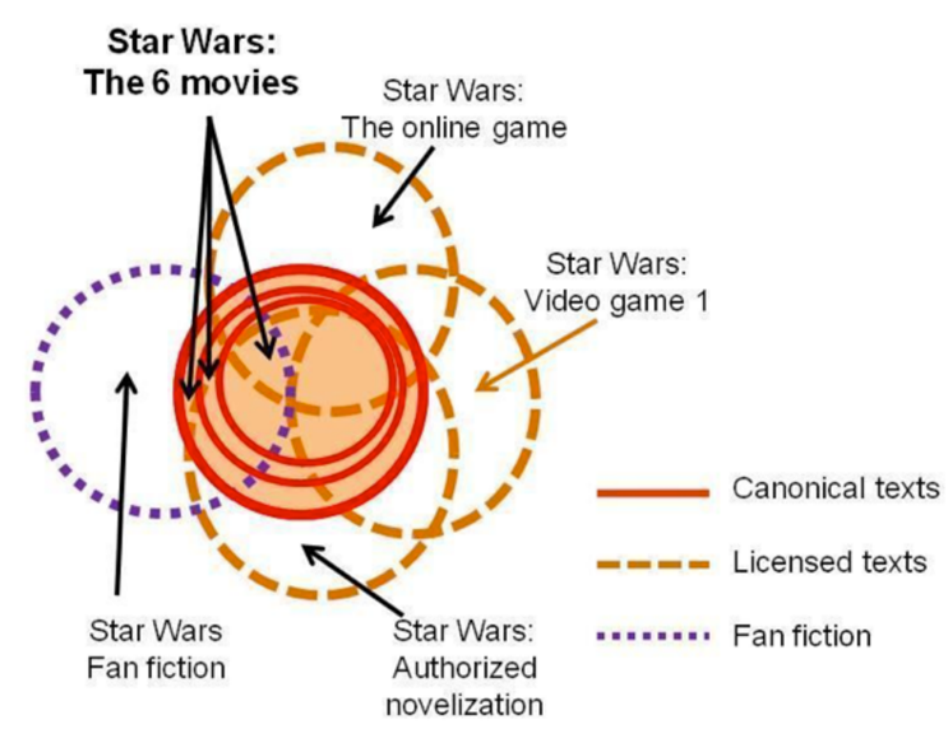

Figura 2_Relações entre universos narrativos no sistema de Star Wars. 
Enquanto um projeto bola de neve consiste, no mais das vezes, em universos sobrepostos, um projeto concebido desde o início como transmídia e convergente pode ser diagramado como a expansão do mesmo universo através de diversos documentos. Como exemplo de um projeto assim, discutirei o caso de Alpha 0.7: Der Feind in dir (Alpha 0.7: $O$ Inimigo Interior), um projeto de narrativa multimídia criado pela rede de TV alemã Südwestrundfunk. Alpha 0.7 foi transmitido entre novembro e dezembro de 2010, e na sua propaganda havia o slogan: “Keine Serie. Ein Universum” (“Não é uma série. Um universo”).

O cerne desse universo é uma minissérie de TV, com duração de 25 minutos em seis partes. Ela narra uma história situada na Alemanha no ano de 2017. Nesse universo, uma empresa chamada Protecta planeja introduzir sistemas de segurança que assumem a forma de uma tecnologia de vistoria cerebral. Quando um indivíduo apresenta o tipo de pensamento que o levaria a um crime violento, suas ideias são alteradas pelo implante de um chip em seu cérebro, e ele é transformado numa pessoa inofensiva. O sistema planejado garantirá uma segurança quase total para os cidadãos alemães, mas violará o direito individual à privacidade. Um movimento clandestino chama ita para manter a liberdade de pensamento. 


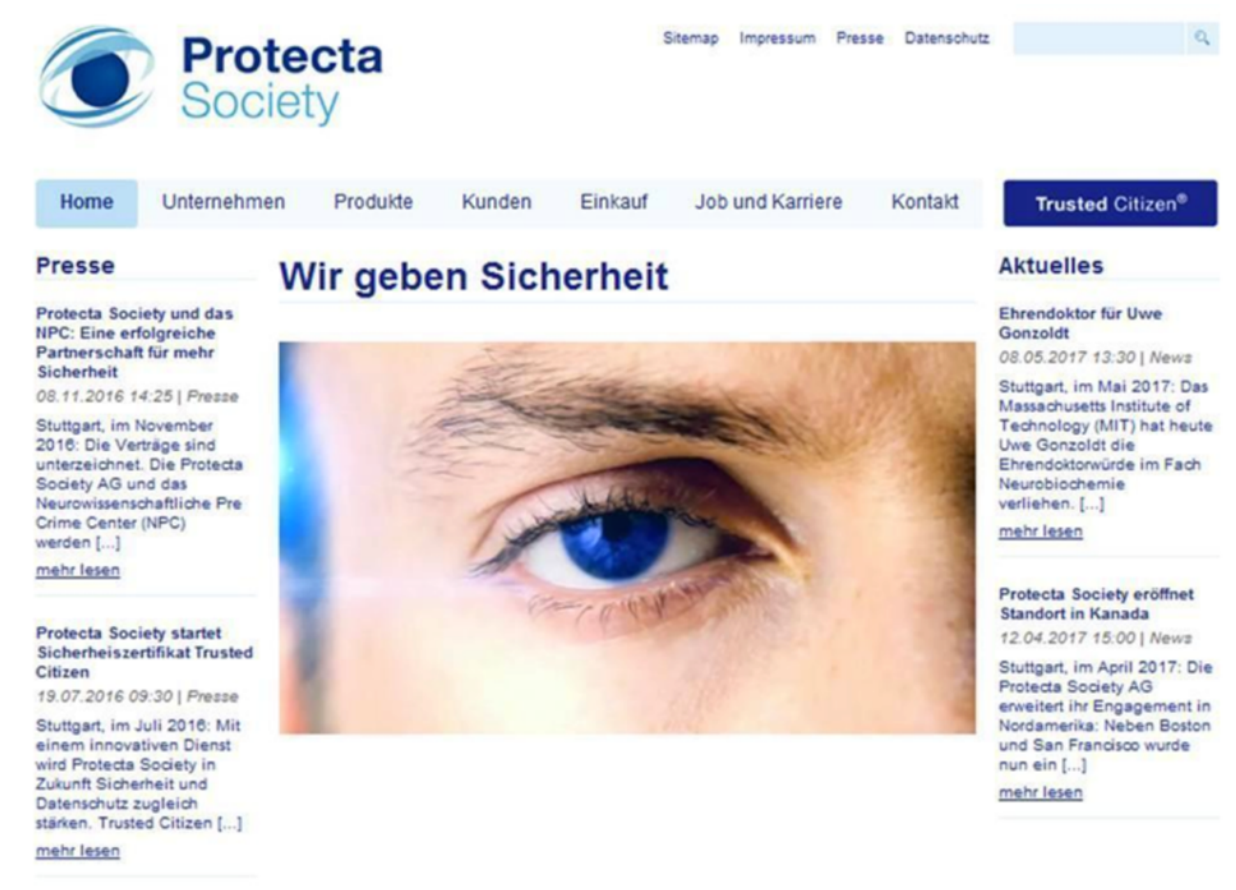

\footnotetext{
Figura 3_Alpha 0.7: 0 site da Protecta. 0 artigo à direita menciona que Uwe Gonzoldt, diretor da Protecta, foi premiado com uma condecoração honorária do MIT [Massachusetts Institute of Technology]. http://www.protecta-society.de/ (http://www.protecta-society.de/)
}

Alpha 0.7 usa a televisão para narrar a história, mas também usa sites de internet e peças de rádio para providenciar documentos suplementares sobre o universo narrativo[31]. Por exemplo, há um blog ficcional mantido por Apollo que discute a perda da liberdade pessoal que está acontecendo nesse universo e o dilema ético de se impor a segurança sobre a população ao custo da privacidade. Há ainda o site da Protecta (figura 3), a empresa que manufatura a tecnologia de vistoria e controle cerebral. Através desse site, que passa por um site de uma empresa real [32], Protecta se apresenta ao público como uma benfeitora da humanidade. A imagem positiva da Protecta é reforçada por um comercial televisivo onde um estuprador convicto louva o sistema de controle cerebral da Protecta porque o transformou num cidadão cumpridor das leis e o salvou de uma vida na cadeia. Há ainda o blog da personagem principal, uma jovem mulher chamada Johanna, que foi contratada pela Protecta como cobaia para testes: a empresa implanta 
um chip no cérebro de Johanna sem que ela o saiba, para assim controlar o seu comportamento. Há também um programa de TV ficcional que relata o desaparecimento de uma personagem chamada Stefan Hartmann (figura 4), e uma página da rede que contém links para o computador de Hartmann. Esses links convidam a usuária a investigar os sites que Hartmann visitava, na esperança de resolver o mistério de seu desaparecimento.
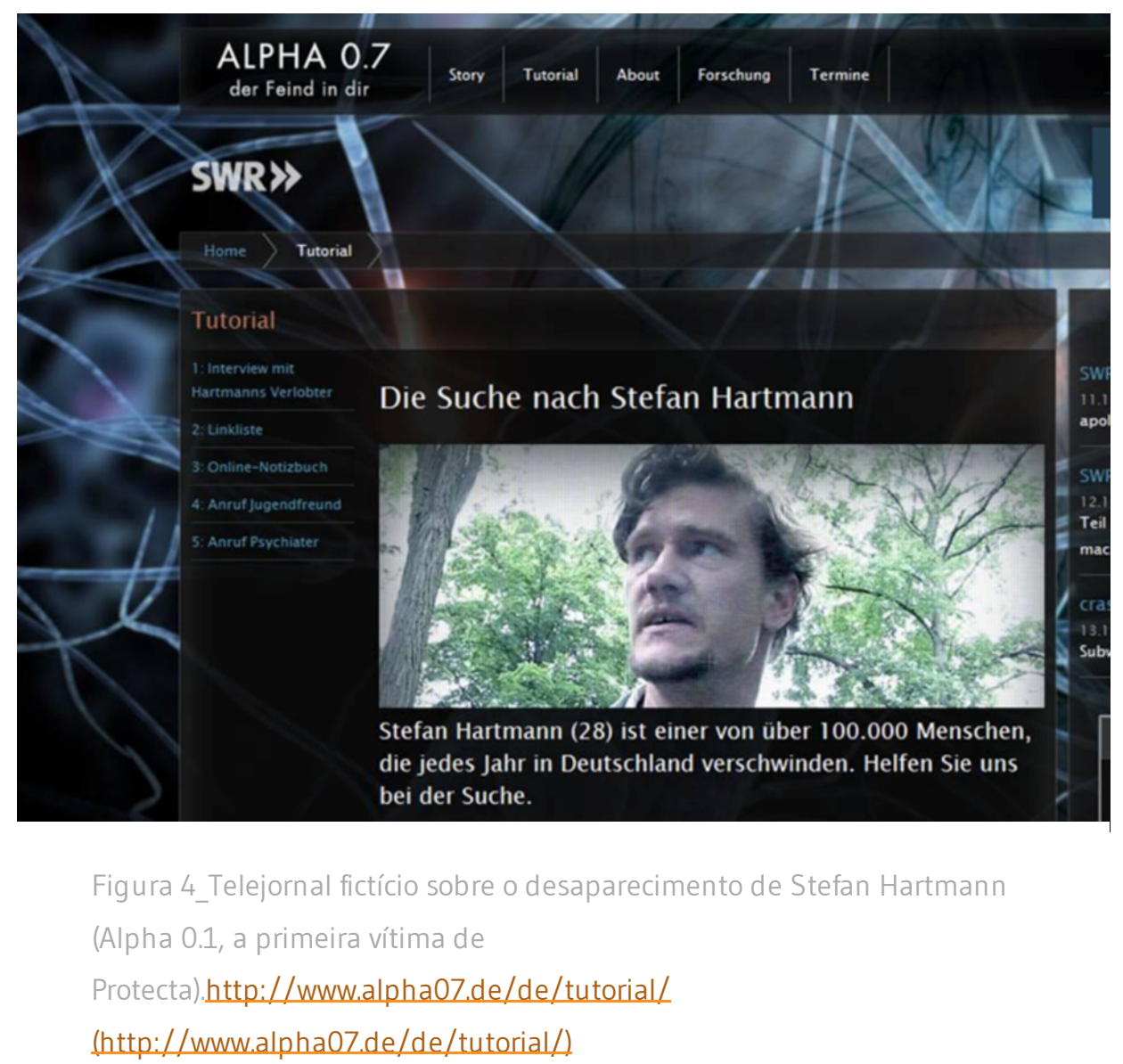

O estatuto ontológico desses documentos é bem diferente do estatuto dos universos em interseção dos sistemas em bola de neve. Num sistema em bola de neve, as mesmas personagens e quase os mesmos acontecimentos aparecem em mídias diferentes: ora num romance, ora num jogo, ora num filme. Mas o romance não existe no universo do jogo, o jogo não existe no universo do filme, e o filme não existe no universo do romance, porque essas várias mídias representam a ação, em vez de 
objetos da mídia: elas não dizem "eu sou um filme, eu sou um romance, eu sou um jogo", mas sim “eis o que aconteceu”. No caso deAlpha 0.7, pelo contrário, a tarefa de representar a ação diretamente é preenchida pelo programa televisivo, mas o filme da ação é suplementado por objetos de mídia que existem dentro de um universo narrativo comum. Num dos episódios para TV, o blog de Johanna aparece na tela como parte da trama e élido por seu marido, que tenta localizá-la depois que ela desaparece. Assim como nós espectadoras fingimos que as imagens na tela da TV são os acontecimentos do universo narrativo, fingimos que o blog na internet real é um blog que existe dentro do universo narrativo.

A função dos documentos da rede é providenciar informações de base que não seriam apresentáveis na mídia do cinema, porque seu foco está na ação e no diálogo. Os documentos escritos permitem descrições muito mais completas das ideias, das emoções e do pano de fundo científico da séria do que a série de TV, porque a leitora está livre para analisar a informação no seu próprio ritmo[33]. Por exemplo, o blog de Johanna explica muito melhor do que o filme a sua decisão de aceitar o emprego na Protecta, sua impressão inicial da empresa e sua relação com o marido e a filha. Aqui, o sistema joga com a complementaridade da natureza semiótica de duas mídias, mas a mídia da linguagem escrita é claramente subordinada à mídia do cinema. O sistema é desenhado para dois tipos de espectadoras: aquelas que assistem apenas à série de TV (a maioria), e aquelas que consultam os outros documentos, mas é muito pouco provável que haja alguém que limite sua visita aos sites, enquanto ignora o programa televisivo: seria como ler descrições num romance e pular as partes de ação.

A apresentação do universo de Alpha 0.7 não para nos documentos ficcionais feitos para o programa. Se observarmos os links no computador de Stefan Hartmann, descobriremos um número de documentos do universo real: por exemplo, uma entrada na Wikipédia sobre estímulo cerebral, outra sobre esquizofrenia paranoide e um artigo da famosa revista alemã Der Spiegel acerca de monstros humanos e o que fazer com eles[34]. Tais documentos existem independentemente do programa e descrevem o universo real, mas, ao conectá-los ao caso do desaparecimento de Stefan Hartmann, o sistema Alpha 0.7 os integra ao 
universo narrativo ficcional e redireciona sua referência para esse universo. Vemos, por exemplo, o artigo da Wikipédia sobre esquizofrenia paranoide aparecer na tela de computador de Johanna durante o programa televisivo. Esse uso de documentos não-ficcionais como blocos construtivos do universo narrativo parece, à primeira vista, violar as fronteiras entre ficção e não-ficção, mas pode ser encarado como uma variação na prática de se referir a indivíduos e acontecimentos do universo real em romances históricos: universos ficcionais sempre se sobrepõem, em algum grau, com o universo real; doutro modo, seriam tão estranhos que não conseguiríamos processá-los. Se esse tipo de sobreposição parece mais estranho do que um romance que se refere a Napoleão, é porque o romance cria uma contraparte imaginária do Napoleão da vida real, e essa contraparte existe apenas no universo narrativo específico desse romance em particular, enquanto no caso de Alpha 0.7 um objeto encontrado fora do sistema Alpha 0.7 - por exemplo, numa busca pelo Google sobre "esquizofrenia paranoide" - é literalmente importado para o universo narrativo. O objeto das mídias, tais como os sites, podem ser descontextualizados e transportados entre limites ficcionais sem dificuldades.

Até o momento, vimos documentos que criam o universo narrativo a partir de duas perspectivas ontológicas diversas: o filme da TV o cria a partir de uma perspectiva externa (extradiegética), já que o filme não existe como objeto dentro desse universo, enquanto os sites ficcionais e os sites reais internalizados criam uma perspectiva interna (intradiegética), como textos que existem dentro do universo narrativo.

Ao contrário dos filmes e sites que criam ativamente o universo narrativo, alguns dos documentos acessíveis pelo site de Alpha 0.7 descrevem-no como um objeto pré-existente e reconhecem sua ficcionalidade, em vez de fazê-lo passar pelo universo real, como um discurso ficcional genuíno[35]. Esses documentos são o que Gérard Genette[36] chamaria de paratextos. Reunidos sob a aba "story" (em inglês no site), eles tratam de categorias como "o mundo em 2017", "as pessoas", "as instituições” e "die Erzählung” (= a narrativa). Os documentos têm duas funções: (1) dão à usuária uma ideia do que tratam o programa de TV e seus documentos satélites, tal como fariam um 
trailer cinematográfico ou a publicidade da contracapa de um livro; (2) explicitamente sugerem conexões entre o universo da série televisiva e o universo factual.

Essa conexão é reforçada por uma última categoria de textos acessíveis a partir de uma aba chamada "pesquisa": documentos do universo real que são apresentados como evidência de que o universo de hoje já contém as sementes da situação distópica representada na série de TV. Ao contrário dos documentos descritos anteriormente, esses textos não estão disponíveis às personagens e não estão, por conseguinte, integrados ao universo narrativo. Vários deles são programas de rádio da Südwestrundfunk que descrevem o estado atual da neurociência. Eles sugerem que as técnicas de ressonância magnética estão cada vez mais próximas de serem capazes de ler os pensamentos e, portanto, de que a tecnologia de vistoria cerebral da Protecta possa mesmo se tornar realidade até 2017. Outro documento do universo real ligado a Alpha 0.7 é um site que descreve um projeto de pesquisa da Segurança Nacional intitulado "Detecção de Intenção Hostil”. Esse link insinua que a Segurança Nacional busca o gênero de projetos que poderia levar à situação apresentada no programa: uma sociedade em que o comportamento do povo é controlado pelo estado. O universo ficcional de 2017 até seria uma criação da imaginação, mas pertence ao horizonte dos desenvolvimentos possíveis do universo de 2010. Através desses documentos, Alpha 0.7 manda uma mensagem típica da ficção científica distópica: uma mensagem que diz: "Este é um universo ficcional, mas se você não fizer alguma coisa, ele vai ser seu universo".

Outro tipo de elementos não-ficcionais no site de Alpha 0.7 são os comentários das espectadoras reunidos sob a aba "Forum". (para um resumo dos vários documentos conectados a Alpha 0.7, (ver figura 5). Aqui, um exemplo de um comentário que, a meu ver, captura perfeitamente a essência do projeto: 


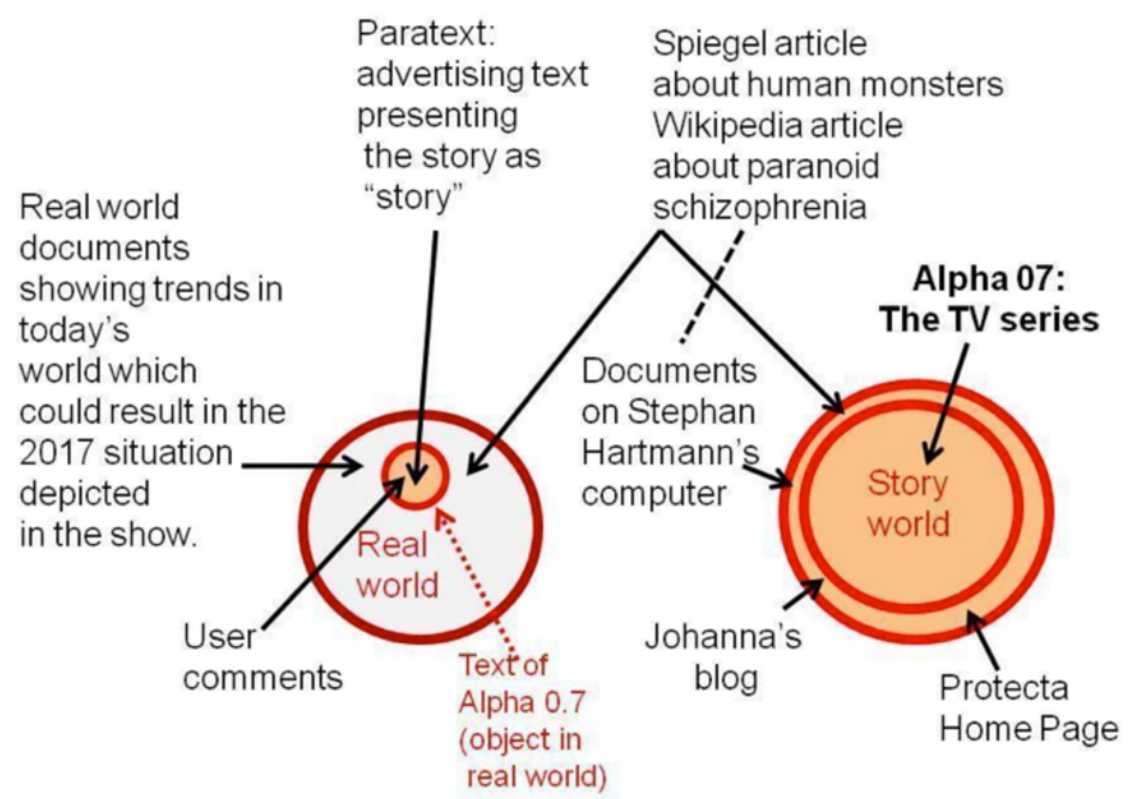

Figura 5_Relações entre os documentos do universo transmídia de Alpha 0.7 .

Wenn ich das Konzept richtig verstanden habe, geht es eben nicht nur um die 25 Minuten, in denen die Sendung im Fernsehen ausgestrahlt wird. Es gibt diese Internetseite hier mit vielen

Hintergrundinformationen, ein Forum zur Diskussion, diverse andere fingierte Webseiten zu dem Thema, Blogs und Videochannels bei Youtube. Ich weiß nicht, wie konsequent die Menschen im

Hintergrund dieses Projektes den Informationsfluss am Laufen halten. Aber wenn in der Woche zwischen den Sendungen immer wieder neue Hinweise, Berichte und Videos auftauchen, können es schnell ein paar Stunden werden, in denen man sich pro Woche mit Alpha 0.7 befasst. Und genau diese Idee fasziniert mich.

Se compreendi corretamente o conceito, há mais em Alpha 0.7 do que os 25 minutos em que o programa de TV é transmitido. Há também as páginas na internet com muita informação de fundo, um fórum de discussão, várias outras páginas da rede inventadas com um tema geral, blogs e vídeos no YouTube. Não sei quão deliberados foram os 
indivíduos na base desse projeto para manter o fluxo de informação. Mas quando novas sugestões, relatos e vídeos continuam a aparecer ao longo da semana, entre os episódios, é fácil passar umas duas horas por semana com Alpha 0.7. E é exatamente essa ideia que me fascina.

Central nesses comentários, ao menos nas primeiras semanas do programa, era uma tentativa por parte das usuárias de resolver os mistérios, tais como a causa de o programa se chamar Alpha 0.7, ou o desaparecimento de Stefan Hartmann. Essas tentativas de resolver os mistérios indicam que Alpha 0.7 era tratado como um Alternate Reality Game [Jogo de Realidade Alternativa], ou ARG. As usuárias tinham dúvidas se seria ou não um ARG, como sugere o seguinte comentário:

\footnotetext{
Was ARG angeht, bin ich mir auch immernoch nicht sicher, ob es eins ist - denn meine Mails an Missing Link wurden noch nicht beantwortet, und unsere Teilnahme an sich ist mir auch noch nicht ganz klar. Vielleicht ist es ein Alternate Reality Experience... Aber es kann sich jederzeit ändern.
}

No que tange a um ARG, ainda não sei se este seria um, pois meus emails para o Missing Link [Elo Perdido] ainda não foram respondidos, e para mim não está claro qual o papel que nós deveríamos representar aqui. Talvez seja uma experiência de Realidade Alternativa... mas isso pode mudar a qualquer momento.

Estava nos planos da Südwestrundfunk[37] incluir um ARG no universo de Alpha 0.7, mas nada surgiu dessa ideia. Esse plano falho nos oferece uma oportunidade de formular a questão de como os ARG's se integrariam numa narrativa transmídia.

\section{JOGOS DE REALIDADE ALTERNATIVA (ARG) COMO PARTE DOS SISTEMAS DE NARRATIVA TRANSMÍDIA \\ Quando os ARG’s são usados como parte de um projeto transmídia, funcionam como uma das muitas plataformas pelas quais o universo narrativo se realiza. Porém os ARG's são também inerentemente narrativas transmídia, já que narram histórias e assim o fazem por fazerem uso de uma ampla gama de sistemas de distribuição pré-}


existentes: sites, emails, mensagens de SMS, GPS, ligações telefônicas, pôsteres, etiquetas e mesmo atores ao vivo, posicionados em espaços reais. No entanto, os ARG's não são meras formas de narração, eles são primariamente jogos, o que quer dizer que são jogados com o intuito de resolver problemas muito mais do que por um interesse intrínseco no conteúdo das narrativas. Elas oferecem um papel muito mais ativo à usuária do que os projetos bola de neve e os universos narrativos inerentemente transmídia que discuti até o momento.

Nos ARG's, pistas para uma narrativa ficcional são espalhadas pelo universo real e pela internet. Em geral, um site serve como ponto de entrada para o universo narrativo, conhecido no jargão como "toca do coelho" [rabbit hole][38]. Por meio de uma convenção conhecida como TINAG ("this is not a game" [isto não é um jogo]), os sites providenciam pistas que parecem ter sido elaboradas para outros propósitos - em outras palavras, eles escondem o fato de que são documentos ficcionais criados especificamente para o jogo. A convenção TINAG é, no geral, encarada como específica dos ARG's, se comparada a outros tipos de jogos (e.g. os jogos esportivos ou de tabuleiro), mas é uma manifestação da convenção básica que subjaz a toda comunicação ficcional. Essa convenção se manifesta de modo mais explícito nos romances do séc. XVIII (como Robinson Crusoe) que se apresentam como cartas verdadeiras ou memórias autênticas. É por negar sua própria ficcionalidade, por tentar passar por verdadeira, que a ficção convida leitoras a participarem do seu jogo de ilusão e a imergirem no universo narrativo. Assim como um romance narra sua história como fato, um ARG a conta por meio de sites que parecem conter informação do universo real.

ARG's são jogados seguindo um rastro de informação que chega a partir de uma variedade de sistemas de distribuição. Por exemplo, um site pode conter um número de telefone; a pessoa que responde à ligação pode indicar um lugar do universo real, que deve ser visitado, onde uma mensagem será transmitida; além disso, a jogadora pode receber emails ou mensagens SMS em seu celular, e assim receberá pistas de atores ao vivo posicionados em determinados lugares. Ao resolver as charadas e se comunicar com outras pessoas, as jogadoras são direcionadas a novas 
fontes de informação que lhes permitem saber mais e mais da história. Em geral, as pistas são tão difíceis, que as pessoas não conseguem resolvê-las por conta própria; para progredirem no jogo, é necessário comunicar-se com outras jogadoras - em outras palavras, formar comunidades. No fim do rastro, as jogadoras resolveram um mistério, tal como uma detetive reúne as peças da história de um caso. A história não é de fato narrada em nenhum dos fragmentos - ela se desenvolve sobretudo na mente das jogadoras. Jane McGonigal, uma das maiores criadoras de ARG's, chama esse modo de apresentação de "narrativa caótica"[39].

Esse modo caótico faz com que seja muito difícil para os estudiosos uma pesquisa sobre a trama dos ARG's: no fim do jogo - que acontece num prazo delimitado - tudo o que resta da inscrição física da narrativa são sites isolados, ou wikis criados pelas jogadoras a fim de trocarem informação sobre o jogo. É bem comum que esses sites e wikis já não sejam mais acessíveis após o fim do jogo, e os únicos vestígios da trama serão os resumos apresentados em documentos paratextuais, como artigos na Wikipédia, ou os documentos privados das criadoras sobre a produção. As narrativas de ARG são fenômenos efêmeros; quando o jogo acaba, $\mathrm{o}$ arquivo público da narrativa desaparece.

Os ARG's foram frequentemente utilizados para promover produtos de outras mídias, sobretudo de TV e cinema. Por exemplo, o primeiro ARG, denominado "The Beast" por suas jogadoras [40], foi concebido como publicidade para o filme AI [Inteligência Artificial] de Steven Spielberg. Houve ainda dois ARG's conectados a Lost, uma série popular de televisão. O problema, quando os ARG's são utilizados em sistemas transmídia, é coordenar sua trama com a história narrada em outros documentos. Essa coordenação envolve não apenas seu conteúdo, como também o espaço de tempo, já que o ARG e o trabalho promovido se desenvolvem num determinado período. Quando um ARG é ligado a um filme ou programa de TV, há três modos de serem conectados no tempo:

1. O ARG precede o lançamento de outra obra, e seu propósito é fazer publicidade. Exemplo: “The Beast” e o filme AI de Steven Spielberg. Nesse caso, a trama do ARG deve constituir um prelúdio opcional ao filme ou 
programa televisivo. Se fosse necessário jogar o ARG para compreender a outra obra, excluiríamos um grande número de espectadoras. (Em "The Beast", as duas narrativas eram bastante independentes uma da outra, mas a narrativa do ARG pode ser vagamente conectada à ação do filme, se encarada como uma pré-história dos robôs apresentados no filme. O ARG cumpriu seu papel promocional porque algumas das pistas eram encontradas nos pôsteres publicitários do filme.)

2. O ARG e outras mídia são concomitantes. Exemplo: a série de TV Lost e os ARG's homônimos, que aconteciam entre as temporadas da série. $O$ ARG, por exemplo, narraria a história de uma personagem que não aparece na série, mas que, de algum modo, é afetada pelos mesmos acontecimentos. Isso era possível em Lost, porque Lost é basicamente uma narrativa paralela com várias personagens; o ARG poderia, sem problemas, acrescentar outra personagem sem arruinar a integridade da série.

3. O ARG segue a outra mídia. Nesse caso, o ARG deve pegar um fio da trama do filme ou do programa de TV que ficou sem nó; por exemplo, um problema que não se resolveu. O risco aqui é que a obra acompanhada não receberá um fechamento típico, e seu final deixará muitas espectadoras frustradas.

Nos três casos, o ARG deve preencher uma condição formulada por Jason Mittel (no prelo): “as extensões transmídia de uma franquia serial devem premiar aqueles que partilham delas, mas não podem punir aqueles que não partilham". Só nos resta especular sobre como um ARG seria ligado a Alpha 0.7, mas ele poderia ter cumprido uma função publicitária ao gerar conversas sobre o assunto nas mídias sociais e assim atrair atenção para as três divisões da Südwestrundfunk: televisão, rádio e internet. Uma maneira pela qual um ARG poderia seguir a série televisiva seria tomar a trama dos programas de rádio, que foram concebidos por suas criadoras como uma "segunda temporada"[41] e transmitidos depois do último episódio para TV. Os programas de rádio são uma sequência clássica: relatam as aventuras de Johanna, que é liberta da Protecta no último episódio televisivo, mas é procurada pela polícia, porque, enquanto Protecta tinha poder sobre sua mente, fizeram 
com que ela tentasse matar o Ministro-Presidente de BadenWürttemberg, que se opunha às vistorias cerebrais. As jogadoras do ARG poderiam receber a tarefa de localizar Johanna, mas o roteiro seria um conteúdo roubado dos programas de rádio.

De modo alternativo, o ARG poderia acontecer durante as seis semanas da série televisiva, desenvolvendo uma linha paralela na trama, presumivelmente centrada numa personagem secundária. Um modo para que o ARG aconteça junto com uma série de TV e cumpra sua função publicitária é esconder pistas do pano de fundo do programa; isso força as jogadoras a escrutinizarem os filmes com minúcia. Já que os episódios de Alpha 0.7 estão disponíveis na internet desde que foram transmitidos pela primeira vez, seria possível que as espectadoras parassem o vídeo em determinados momentos para ler códigos secretos no fundo. Creio que foi isso que fez o fã supracitado: ele encontrou um endereço de email sob o nome de "Missing Link"[42] e enviou-lhe uma mensagem, mas não recebeu resposta, porque não havia um ARG. As palavras "Missing Link" bem poderiam ter sido plantadas pelos produtores como uma "toca do coelho" destinada a funcionar como um portal para o universo-dentro-do-universo do ARG. Quando o projeto para um ARG foi abandonado, também teriam abandonado a "toca do coelho".

Quando deixaram de lado a ideia de um ARG, as criadoras tentaram gerar uma atividade de fãs criando um telejornal fictício sobre o desaparecimento de Stefan Hartmann[43]. Ao anunciar que “o computador de Stefan Hartmann foi encontrado", o telejornal convidava a espectadora a tentar resolver o caso explorando os sites que Stefan Hartmann havia visitado antes do seu desaparecimento. Um fã identificou os nomes de sete indivíduos que foram utilizados no teste dos chips cerebrais da Protecta ao explorar a possibilidade de parar o vídeo dos filmes televisivos. Num episódio, vemos Uwe Gonzoldt, diretor da Protecta, folhear uma pilha de arquivos; as páginas se movem rápido demais para que uma espectadora consiga capturar a informação na TV; mas, se o vídeo é pausado, é fácil ler os nomes em cada arquivo. Esses nomes correspondem aos vários Alphas: Stefan Hartmann é Alpha 0.1; Johanna Berger, Alpha 0.7. No entanto, depois que os nomes foram 
identificados, não havia nada mais que as fãs pudessem fazer, senão assistir às aparições ocasionais de Stefan Hartmann na série televisiva. (Nós o vemos contatar Apollo, o grupo de resistência, e depois suicidarse enquanto é perseguido por pistoleiros da Protecta.)

A questão do elo entre a série de TV e um ARG aponta para um problema central na criação de sistemas narrativos transmídia: os documentos individuais devem chegar a um fechamento razoável para que satisfaçam à usuária que se utiliza da mídia, porém devem ser suficientemente abertos para que gerem um conteúdo adicional. As várias mídias estabelecem tanto uma relação competitiva como cooperativa: quando uma parte da narrativa é dada numa mídia, deve ser retirada de outra para evitar a redundância [44]. Uma certa quantidade de redundância é considerada positiva, desde que torne a narrativa acessível a pessoas que consomem documentos diversos, mas deve ser mantida dentro de certos limites: nisso reside a arte da narrativa transmídia. O modo tradicional de controlar um compromisso entre fechamento e abertura é apresentar cada um dos vários componentes como uma batalha vencida numa guerra constante. Em Alpha 0.7, a batalha vencida no fim da série televisiva é o fato de que Johanna conseguiu remover o chip de seu cérebro e, portanto, se libertou do controle da Protecta; mas, na última cena, os líderes da Protecta reafirmam o interesse em impor seu sistema sobre a sociedade, dando assim continuidade à guerra. Para que um sistema transmídia permaneça produtivo, as forças negras nunca serão derrotadas para sempre. De acordo com a teologia cristã, a eliminação de todo o mal seria o fim do universo - o que implica o fim dos universos narrativos.

\section{A CRIAÇÃO DE SISTEMAS NARRATIVOS TRANSMÍDIA}

O último ponto que eu gostaria de analisar é sobre quais gêneros de narrativas, ou tramas, se concedem a projetos transmídia. Para discutir essa questão, meu ponto de partida será a seguinte observação de um cineasta anônimo a Henry Jenkins:

\footnotetext{
Quando comecei, a gente montava uma história, porque sem uma boa história você não tem um filme de verdade. Depois, quando começaram a crescer as sequências, a gente montava uma
} 


\begin{tabular}{ll|l}
\hline celeuma & número $3 \mid$ dezembro 2013 & dossiê \\
\hline
\end{tabular}

personagem, porque uma boa personagem dá base a várias narrativas.

Agora, a gente monta um universo, porque um universo dá base a

múltiplas personagens e múltiplas narrativas através de múltiplas

mídias.[45]

No entanto, um universo narrativo não consegue uma identidade distintiva sem personagens que o habitem, e as personagens não conseguem uma identidade sem algum tipo de história pessoal que as acompanhe: o que significa afinal "montar um universo", em oposição a "montar uma história", ou "montar uma personagem"?

Eu encaro "formar uma narrativa" como criar uma narrativa cujo ponto central de interesse jaz na trama e que minimiza a representação de "como se sente"[46] quem passa por determinados acontecimentos. Esse foco na trama é claramente o caso dos contos de fada: Cinderela, Chapeuzinho Vermelho, João e Maria e o herói dos contos populares de Propp não têm uma personalidade que transcenda os acontecimentos de que tomam parte. Quando o herói ganha a princesa no fim do conto, eles vivem felizes para sempre, e não há necessidade de uma sequência, porque nem o herói, nem sua esposa tem uma individualidade que embase uma nova história. Outro tipo de narrativa centrada na história é a tragédia: como observara Aristóteles (Poética 4.3), a tragédia é dominada pela ação dramática. A trama dos contos de fada e da tragédia apresenta um tal fechamento que não há espaço para expansões. Não digo que histórias centradas na trama não possam inspirar operações transficcionais[47]; mas, quando isso acontece, a operação é predominantemente a transposição, e vez por outra a modificação. Por exemplo, como demonstrou Het Pyrhonen[48], há incontáveis versões do conto do Barba Azul que situam a estrutura básica da trama num cenário diferente, mas seria um desafio fazer com que a leitora se interesse por um Barba Azul jovem que ainda não matou nenhuma esposa, ou pelo segundo casamento da esposa que sobreviveu a ele.

Montar uma personagem significa criar um indivíduo ficcional que parece possuir uma vida própria e que instiga a usuária a imaginar como tal indivíduo reagiria em diversas circunstâncias. Porém, quando a narrativa original cobre um longo período, e quando a personagem 
passa por uma evolução psicológica nesse período, é muito difícil apresentar novos episódios junto com esse arco narrativo, porque nesses novos episódios a personagem estaria presa num estado intermediário. Uma narrativa sobre Emma Bovary após seu casamento, mas antes dos seus casos amorosos, perderia seu desenvolvimento e, portanto, não seria muito interessante. Por esse motivo, as personagens memoráveis, que inspiram narrativas e mais narrativas, tendem a ser tipos de superheróis que não evoluem de um episódio para outro: tipos como Odisseu, Sherlock Holmes, Indiana Jones ou James Bond. Nesse caso, o universo narrativo se desenvolve através de um acúmulo de episódios que seguem um padrão narrativo tradicional e repetível ao infinito, o padrão dos problemas individuais resolvidos pelo herói. O universo narrativo cresce mais e mais, mas não muda de fato, ou de modo significativo.

O que é necessário para que uma narrativa monte um universo inteiro, em vez de uma personagem? Tal universo deve conter características invariáveis, para que seja reconhecido como a estrutura de referência de diversos documentos. Mesmo quando a narrativa não é centrada na personagem, a identidade do seu universo depende da recorrência de certas personagens identificadas por nomes que funcionam como designadores rígidos [49] - nomes que nos digam que "Darth Vader" num romance ou videogame é uma contraparte do Darth Vader dos filmes, e não mero homônimo. Uma ampla rede de personagens conectadas por relações familiares, ou reunidas pelas circunstâncias da vida ficcional, é uma condição particularmente favorável para um sistema narrativo centrado no universo. Como já nos mostraram os universos de Faulkner e Balzac, as personagens que ocupam um papel central em algumas narrativas do sistema podem aparecer como personagens menores em outras narrativas.

Entretanto, para que embase um amplo sistema narrativo, o universo ficcional deve ainda apresentar diversidade. Isso não quer dizer que precise necessariamente abarcar um território amplo; quer dizer que o universo precisa ser imaginado por suas criadoras com muitos detalhes, para que seus vários aspectos sejam descritos em diferentes documentos. Se Lord of the Rings teve tanto sucesso ao atravessar múltiplas mídias, isso se deu em parte porque fora imaginado por seu autor com mais 
minúcia do que outros universos fantásticos, tais como os universos de cada conto de fada. Como observa Jenkins (com base na teórica das novas mídias, Janet Murray), um universo narrativo transmídia deve ter uma capacidade enciclopédica [50]. Deve inspirar a mesma paixão que leva algumas pessoas a passarem horas pesquisando história familiar, história militar e a vida de sua celebridade favorita, a criarem mapas e enciclopédias online para os universos dos romances populares[51], ou a construírem seu próprio universo imaginário na internet[52]. Tal paixão pode ser uma curiosidade etnográfica por instituições, grupos étnicos, história, geografia e tradições culturais do universo narrativo, ou mesmo motivada pelo desejo de resolver um mistério. Um tema muito adequado a encorajar a atividade detetivesca é o tema da conspiração, porque sugere que, sob a superabundância de informação que o universo narrativo lança sobre as usuárias de modo aparentemente aleatório, há um rastro significativo de sinais que leva a uma compreensão racional da realidade. Essa ideia de que tudo fará sentido, uma vez que os signos sejam corretamente decifrados, é a motivação que dispõe as jogadoras de ARG's a consumirem seu tempo na caça de pistas escondidas.

No caso de Alpha 0.7, a principal fonte de motivação para explorar os vários documentos é a crença de que o universo ficcional representa $\mathrm{o}$ futuro do universo real. O apelo de Alpha 0.7 não reside na ação narrativa - o programa é um suspense bastante convencional que emprega muitos truques baratos na trama, tais como viradas súbitas de motivação paupérrima[53]-, ele está na dramatização de questões éticas que dizem respeito a todos: o dilema entre segurança e liberdades pessoais e a crescente habilidade da ciência cerebral em conhecer e controlar a mente. As criadoras de Alpha 0.7 tiveram muito mais sucesso na criação de um universo do que na criação de uma narrativa; mas a série de TV é boa o suficiente para fornecer uma diretriz às usuárias através do universo narrativo e a motivá-las a saber mais sobre o assunto.

\section{CONCLUSÃO}

Por que os projetos transmídia são tão populares hoje? Eu consigo pensar em seis respostas:

1. Um truque de marketing. Sistemas narrativos transmídia nos são 
impostos de cima para baixo pelas criadoras. O intuito das criadoras não é artístico, mas econômico: a narrativa transmídia é apenas um modo de fazer com que consumamos tantos produtos quanto possível. Esse é certamente o caso de Alpha 0.7: a Südwestrundfunk é uma empresa que vende serviços de TV, rádio e internet, as três mídias em que a narrativa foi distribuída. (Na verdade, alguns dos programas de rádios linkados na rede têm uma conexão tão remota com a narrativa, que o propósito do link é obviamente promocional.)

\section{O prazer da experimentação. Sempre que novas mídias são} desenvolvidas, há um forte ímpeto de usá-las com fins artísticos e de entretenimento que vão além da função para as quais elas foram originalmente elaboradas. A narrativa transmídia é uma resposta à proliferação de mídias e sistemas de distribuição que nos trouxe a revolução digital dos últimos 50 anos. Ela oferece à audiência uma oportunidade de utilizar seus últimos gadgets eletrônicos, tais como os smartphones, tablets e GPS. Tal motivação é particularmente forte no caso dos ARG's.

3. A necessidade de narrativas comunitárias. Quando um corpus narrativo adquire um estatuto que defina sua identidade para um grupo, ele tende a se espalhar por múltiplas mídias, tal como já nos demonstrou o tratamento das narrativas bíblicas. Graças a um efeito circular de interações, a capacidade dessas narrativas para criar comunidades mundiais inspirou franquias transmídia, e essas franquias reforçaram o poder das narrativas para criar comunidades.

\section{Personalização do tempo. Projetos como Alpha 0.7 dão às usuárias a} possibilidade de pesquisar o universo narrativo na rede e, portanto, de passarem o tempo que quiserem no assunto, em vez de lhes impor pela mídia a duração da sua imersão. (cf. as afirmações do fã supracitado) Os documentos individuais de uma narrativa transmídia exigem um tempo específico - tempo de ler, tempo de assistir -; mas a usuária está livre para decidir quantos documentos pretende consultar e, por conseguinte, até onde pretende explorar o universo narrativo.

5. Mídias passíveis de download. A possibilidade de fazer download de 
vídeos ou peças de teatro implica duas coisas para a narrativa transmídia: (1) as usuárias não estão mais presas a cronogramas rígidos de tempo a fim de acessarem os documentos que embasam o universo narrativo; por exemplo, com Alpha 0.7 , se você perder a transmissão do episódio na TV, é possível vê-lo online no dia seguinte. (2) Esses documentos podem ser pausados e repetidos, de modo que são estudáveis como um texto literário, ou uma figura imóvel. Por exemplo, as espectadoras que pensavam que Alpha 0.7 estava conectado a um ARG tentaram encontrar número de telefones ou endereços de sites escondidos no fundo.

\section{Retorno do investimento cognitivo. Por fim, há um motivo que opera não apenas no caso de narrativas transmídia, mas também em transficcionalidades seriais e monomídia: uma vez que investimos uma energia mental suficiente para construir um universo narrativo, queremos cobrar os dividendos dos nossos esforços com possibilidade de retornar a esse universo quantas vezes desejarmos. A imersão por vezes toma bastante tempo para se desenvolver, mas com narrativas, séries e transficcionalidades transmídia, já estamos imersos quando novos acontecimentos são narrados, porque nossa imaginação já construiu um lar duradouro no universo narrativo.}

[1] NOTA DO TRADUTOR: Todo o artigo é escrito com base nas palavras story, storytelling, worldstory e world; por isso, para manter uma unidade na tradução, tentei, tanto quanto possível, verter as duas primeiras palavras por narrativa, e as duas últimas por universo narrativo e universo; mas, dadas as especificidades da língua inglesa, vez por outra optei por outras soluções que melhor explicitassem o uso a cada momento. Outro detalhe importante na estilística da autora é a feminilização de figuras abstratas (reader, author, spectator, player, viewer, fan, etc.); o que me levou a marcar deliberadamente essas abstrações no feminino em português.

[2] A escrita deste artigo só foi possível graças a Johannes Gutenberg Fellowship na Universidade de Mainz, Alemanha, entre 2010 e 2011. Sou muito grata ao Professor Karl Renner, que me apresentou a equipe de produção de Alpha 0.7 e me deu imenso apoio na pesquisa ao longo da minha estaia na Alemanha, bem como ao meu assistente, Jan-Noël Thon, que cuidou de todos os problemas práticos. Algumas versões deste artigo foram apresentadas nas universidades de Hamburgo, Passau, Bolonha, Basileia, Tubingena e Giessen, além de Ohio State University; e agradeço às audiências pelas estimulantes discussões. Uma versão alemã deste artigo “Transmediales Storytelling und Transfiktionalität” está no prelo em MedienErzählen- Gesellschaft, eds. Karl Renner, Dagmar von Hoff und Matthias Kringel (Berlim: Walter de Gruyter).

[3] Saint-Gelais, Ricard. "Transfictionality." In. The Routledge Encyclopedia of 
Narrative Theory. David Herman, Manfred Jahn and Marie-Laure Ryan

[Eds.].London: Routledge, 2005. p. 612-13

[4] Jenkis, Henry. Convergence Culture: Where Old and New Media Collide. New York: New York University Press, 2006; Dena, Christy. Transmedia Fictions:

Theorising the Practice of Expressing a Fictional World across Distinct Media and Environments. Ph.D. Dissertation, University of Sidney; J.P. Wolf, Mark. Building Imaginary Worlds: The Theory and History of Subcreation. London: Routledge, 2012; Mittel, Jason. "Strategies of Storytelling on Transmedia Television," in. Marie-Laure Ryan and Jan-Noël Thn [Eds.]. Storyworlds Across Media. Lincoln: University of Nebraka Press, 2014. No prelo.

[5] Jenkis, Henry. Convergence Culture...

[6] Jenkis, Henry. Convergence Culture. p.95

[7] Depois, em seu blog, Confessions of an Aca-Fan

(http://henryjenkins.org/2007/03/transmedia_storytelling_101.html (http://henryjenkins.org/2007/03/transmedia_storytelling_101.html)), Jenkins propôs uma definição mais detalhada, porém mais limitada; como veremos rapidamente, ela não se aplica ao que eu chamo de efeito "bola de neve": A narrativa transmídia representa um processo em que elementos integrais de uma ficção são dispersos sistematicamente em diversos canais com o intuito de criar uma experiência de entretenimento unificada e coordenada. Idealmente, cada mídia faz sua própria contribuição específica. (Itálicos no original)

[8] (N.T.) Embora o termo não seja dicionarizado em português, uso-o para traduzir o inglês prequel por já ter se tornado um jargão do cinema.

[9] Os filmes de Harry Potter e Lord of the Rings são bastante conhecidos. Foram lançadas entre 2001 e 2011, pela EA Games, oito adaptações para videogame dos romances Harry Potter. A Wikipédia lista 24 jogos (para uma ou várias usuárias) baseados na série do Senhor os Anéis, desde 1982.

[10] Jenkis, Henry. Convergence Culture. p. 93-103

[11] Dena, Christy. Transmedia Fictions: Theorising the Practice of Expressing a Fictional World across Distinct Media and Environments. Ph.D. Dissertation, University of Sidney, p. 99-104. Dena propôs uma categorização de projetos transmídia que é próxima à distinção aqui proposta entre projetos "bola de neve" e projetos concebidos desde o início como uma propagação entre múltiplas mídias. Ela chama os dois gêneros de projetos transmídia de "intercomposicionais" (= envolvem diversas composições separadas) e "intracomposicionais" (= envolvem apenas uma composição).

[12] Ver David Herman. Basic Elements of Narrative. Malden, MA: WileyBlackwell, 2009. p. 105-36 para uma tentativa de definição desse conceito. Ele tem sido utilizado há muito tempo pelos críticos literários, mas de modo informal. [13] Bakhtin, Mikhail. "Forms of Time and the Chronotope in the Novel.," in. The Dialogic Imagination: Four Essays by M.M. Bakhtin. Michael Holquist [Ed.].Caryl Emerson, Michael Holquist [Trad.]. 84-258 (Austin: University of Texas Press, 1981. P. 84-258.

[14] Para evitarmos um jargão narratológico desnecessário, uso "trama" no sentido informal de "sequência de acontecimentos contados pela narrativa", i.e, como um sinônimo de "história" ou "fábula". É nesse sentido que falamos de "grandes tramas" ou "lacunas na trama".

[15] Klastrup \& Tosca (“Transmedial Worlds-Rethinking Cyberworld Design.” Disponível In. www.itu.dk/courses/DDRT/F2008/25042008-tosca.ppt (http://www.itu.dk/courses/DDRT/F2008/25042008-tosca.ppt)) propõem uma taxonomia interessante para aquilo que chamam de "características centrais" [core features] de universos transmídia, características que correspondem ao meu componente estático: eles dividem em Mythos, Topos e Ethos (os rótulos são autoexplicativos). Minha categoria 2 (folclore e pano de fundo) é claramente parte de Mythos; 3 (espaço com características geográficas), parte de Topos; e 5 (regras e valores sociais), parte de Ethos. As categorias 1 (inventário) e 4 (leis físicas) também 
se encaixariam em Topos, se Topos englobar todas as características e leis físicas do universo. Deve-se notar que a taxonomia de Klastrup \& Tosca omite acontecimentos e, por conseguinte, descreve apenas o que eu chamo de componente estático dos universos narrativos.

[16] Bunia, Remigius. "Diegesis and Representation: Beyond the Fictional World, on the Margins of Story and Narrative.” Poetics Today. 2010. P. 713

[17] Jenkis, Henry. Convergence Culture. p.116

[18] Saint-Gelais, Richard. "Transfictionality.” In. The Routledge Encyclopedia of Narrative Theory. David Herman, Manfred Jahn and Marie-Laure Ryan [Eds.].London: Routledge, 2005.

[19] Doležel, Lubomír. Heterocosmica: Fiction and Possible Worlds. Baltimore: Johns Hopkins University Press, 1998. p. 206-07.

[20] Na verdade, Doležel chama a modificação [modification] de deslocamento [displacement]. Eu prefiro modificação, porque deslocamento sugere os fenômenos abarcados pela transposição.

[21] Doležel, Lubomír. Heterocosmica. p 207

[22] Tomo emprestada essa questão de Jason Mitchell (no prelo), que distingue as versões de universos narrativos entre "o que é" (expansões) e "e se" (modificações). [23] Doležel, Lubomír. Heterocosmica. p 206.

[24] Os Novos Sofrimentos do Jovem W., na verdade, envolve tanto modificação como transposição: o herói não comete suicídio, como o Werther de Goethe, mas morre num acidente. Transposição sem modificação é um caso raro; pode ser ilustrado pelas encenações de tragédias gregas em uma roupagem moderna.

[25] Os dois exemplos me foram sugeridos durante apresentações orais deste artigo, mas não posso atestar sua autenticidade, sobretudo no exemplo de Star Wars/Lord of the Rings. Ainda assim, o fato de que poderiam ocorrer torna a citação teoricamente viável como um tipo de relação transficcional. É possível se questionar por que o efeito seria dissonante e incongruente; se não fosse, o elemento importado se encaixaria perfeitamente no universo narrativo, e as marcas de citação implícita desapareceriam.

[26] Ryan, Transfictionality Across Media," in Theorizing Narrativity, edited by John Pier and José Angel García. Berlin, 385-417 (Berlin: De Gruyter), p 399.

[27] Scolari, Carlos Alberto. “Transmedia Storytelling: Implicit Consumers, Narrative Worlds, and Branding in Contemporary Media Production." International Journal of Communication 3: 586-606.

[28] Scolari menciona uma quarta categoria: conteúdo gerado por usuárias, tais como blogs, wikis, ficção de fãs, etc. Mas o conteúdo gerado por usuárias não pertence ao mesmo nível de análise que as outras categorias, já que pode pertencer a qualquer uma delas. Além disso, blogs e wikis não são necessariamente parte de um sistema narrativo; eles podem consistir em comentários de usuárias que avaliam o universo narrativo de uma perspectiva externa, mas não contribuem para sua criação.

[29] Gwenllian Jones, Sara. "Slash Fiction," in. David Herman, Manfred Jahn and Marie-Laure Ryan [Eds.]The Routledge Encyclopedia of Narrative Theory. London: Routledge. 2005. p. 536-37

[30] A característica mais distintiva de Star Wars é o tema da rivalidade entre pai e filho, uma rivalidade que atinge seu clímax num confronto que leva um deles à morte. Esse tema ocorre em muitas narrativas no mundo inteiro, mas não é tão comum quanto a batalha entre o bem e o mal. Duvido que a rivalidade entre pai e filho seja, por si só, suficiente para uma audiência reconhecer a história encenada num ambiente medieval como uma transposição da trama de Star Wars. A conexão seria feita apenas se a similaridade no nível da trama fosse reforçada por pistas visuais, ou nomes relacionados.

[31] A descrição que apresento dos documentos que criam o universo transmídia de Alpha 0.7 é baseada na configuração e no conteúdo do site em 2011. Desde então, ele evoluiu, e mais informação - sobretudo paratextual - foi acrescentada. Alpha 
0.7. Transmedial narrative. http://www. Alpha (http://www. Alpha) 0.7.de/ [32] A ilusão de realidade é reforçada por um botão que diz "contato", mas se alguém clica e envia um email para Protecta, recebe uma reposta que reconhece o estatuto ficcional da empresa.

[33] Os espectadores também podem controlar o tempo de projeção quando o filme é capturado em vídeo, mas até o momento só conseguem parar o vídeo e reiniciá-lo de outro ponto, no ritmo inerente à gravação. Eles não conseguem passá-lo em slow ou fast motion - ao menos não com o equipamento mais disponível.

[34] Esse artigo era a matéria de capa de Der Spiegel (5 de maio de 2008) sobre o caso de Josef Fritzl. Ver http://www.spiegel.de/Spiegel/print/d-56831267.html (http://www.spiegel.de/Spiegel/print/d-56831267.html)

[35] Walton, Kendall. Mimesis as Make-Believe: On the Foundations of the Representational Arts. Cambridge, Ma: Harvard University Press, 1990; Ryan, Marie-Laure. Possible Worlds, Artificial Intelligence and Narrative Theory. Bloomington: Indiana University Press. 1991.

[36] Genette, Gérard. Palimpsests: Literature in the Second Degree, translated by Channa Newman and Claude Doubinsky. Lincoln: University of Nebraska Press. [37] Segundo me disseram os membros da equipe de produção durante uma apresentação pública do projeto em SWR, Mainz, em novembro de 2010.

[38] Por referência à "toca do coelho" que leva Alice ao universo onírico do País das Maravilhas em Alice in Wonderland [Alice no País das Maravilhas] de Lewis Carroll.

[39] McGonigal, Jane. Reality is Broken. London: Penguin Press, 2011. p. 287

[40] Ver artigo sobre “The Beast” na Wikipédia:

http://en.wikipedia.org/wiki/The_Beast_(http://en.wikipedia.org/wiki/The_Beast_) (game)

[41] Hünerfeld, Sebastian e Flächer, Bettina, coprodutores de Alpha 0.7, em conversa pessoal

[42] No universo narrativo de Alpha 0.7, "Missing Link" é o nome de uma organização que procura pessoas que desapareceram misteriosamente, uma ocorrência comum nesse universo.

[43] Sebastian Hünerfeld, conversa pessoal.

[44] Um bom exemplo de projeto transmídia que sacrifica a integridade de seus componentes individuais ao dar o que pertenceria a uma mídia para outra mídia é mencionado por Klastrup \& Tosca: “[N]o filme The Matrix Reloaded (2003), [...] a narrativa de como o grupo de Niobe consegue cortar a energia elétrica para que os heróis realizem sua última missão nunca é mostrada, porque é parte do videogame ("Enter the Matrix", 2003) que a jogadora deve completar sozinha." (“Transmedial worlds”.). A lacuna na trama não causa, porém, um grande estrago, porque a espectadora está distraída da lógica narrativa graças aos efeitos especiais.

[45] Jenkis, Henry. Convergence Culture. p. 116)

[46] Um aspecto da história que Fludernik (Towards a 'Natural' Narratology. London: Routledge. 1996) encara como constitutivo de uma narrativa. Creio, ao contrário, que possa ser mais ou menos desenvolvido, mas não substitui a trama como uma condição necessária à narratividade.

[47] O conteúdo da tragédia grega foi, é claro, objeto de pesada atividade transficcional/transmídia que também incluía artes visuais, poesia lírica e épica; mas tal atividade é típica das sociedades orais, e a cultura grega acabava de emergir de uma fase oral. No entanto, enquanto as personagens individuais viajavam facilmente entre gêneros e mídias, as tramas não: como observara Aristóteles (Poética 8.7), certas tramas são adequadas à poesia épicas, outras ao drama. [48] Pyrhonen, Heta. Bluebeard Gothic: Jane Eyre and its Progeny. Toronto: University of Toronto Press, 2010.

[49] A teoria do "designador rígido" para os nomes, desenvolvida por Saul Kripke (Kripke, Saul."Naming and Necessity," in Semantics of Natural Language, edited by Donald Davidson and Gilbert Harman, 253-55 (Dordrecht: Reidel), 1972), alega 
que o nomes não representam certos feixes de propriedades, mas são ligados a certos indivíduos em diferentes universos possíveis graças a um ato originário de batismo. Segundo essa teoria, as propriedades de Darth Vader podem mudar substancialmente de universo para universo e de texto para texto, sem afetar sua conexão com o Darth Vader original. No entanto, deveríamos perguntar se não haveria propriedades essenciais inalteráveis: duvido que um cachorro branco fictício chamado Darth Vader seria reconhecido como uma contraparte do vilão de Star Wars.

[50] Jenkis, Henry. Convergence Culture. p 116

[51] Tal como A Song of Ice and Fire [As Crônicas de Gelo e Fogo] de George R. R. Martin, que não apenas gerou um império transmídia (romances, séries televisivas, jogos), mas também inspirou sites que aspiram a reunir tudo que é possível saber sobre seu universo narrativo. Cf. http://towerofthehand.com/

(http://towerofthehand.com/)

[52] Aqui penso nas pessoas que constroem micronações imaginárias ao postar sua descrição na internet. Exemplos de micronações são Bergônia, Talossa, Uteged, Reunião, Lizbekistan, Freedônia e Aristasia, o Império Feminino. Ver Marie Laure Ryan. "Fictional Worlds in the Digital Age,"in:. A Companion to Digital Literary Studies, 2007.

[53] Por exemplo, Johanna é capturada pela Protecta e depois se liberta, como que por milagre; mais adiante, ela cai facilmente numa armadilha feita pela Protecta e é capturada outra vez.

MARIE-LAURE RYAN é pesquisadora independente no campo da narratologia e da cultura digital, tendo publicado uma série de livros e artigos que são referência na área. Vai lançar, em 2014, Storyworlds Across Media, com Jan-Noel Thon (University of Nebraska Press) e The Johns Hopkins Guidebook to Digital Humanities, com Lori Emerson e Benjamin Robertson.

Tradução de Guilherme Gontijo Flores 